\title{
Bovine respiratory disease associated with Histophilus somni and bovine respiratory syncytial virus in a beef cattle feedlot from Southeastern Brazil
}

\section{Doença respiratória bovina associada a Histophilus somni e vírus respiratório sincicial bovino em um confinamento de bovinos de corte na região sudeste do Brasil}

\author{
Selwyn Arlington Headley ${ }^{*}$; Luciana Carvalho Balbo ${ }^{2}$; \\ Alice Fernandes Alfieri'; João Paulo Elsen Saut ${ }^{3}$; Anderson Lopes Baptista ${ }^{4}$; \\ Amauri Alcindo Alfieri ${ }^{1}$
}

\begin{abstract}
Bovine respiratory disease (BRD) is a complex multifactorial and multi-etiological disease entity that is responsible for the morbidity and mortality particularly in feedlot cattle from North America. Information relative to the occurrence of BRD in Brazil and the associated infectious agents are lacking. This study investigated the participation of infectious agents of BRD in a beef cattle feedlot from Southeastern Brazil. Nasopharyngeal swabs of $11 \%(10 / 90)$ of cattle $(n, 450)$ with clinical manifestations of respiratory distress were analyzed by targeting specific genes of the principal infectious pathogens of BRD. In addition, pulmonary fragments of one the animals that died were collected for histopathological and molecular diagnoses. The nucleic acids of Histophilus somni and bovine respiratory syncytial virus (BRSV) were identified in $20 \%(2 / 10)$ of the nasopharyngeal swabs of the animals with respiratory distress; another contained only BRSV RNA. Moreover, the nucleic acids of both infectious agents were amplified from the pulmonary fragments of the animal that died with histopathological evidence of bronchopneumonia and interstitial pneumonia; the nasopharyngeal swab of this animal also contained the nucleic acids of both pathogens. Additionally, all PCR and/or RT-PCR assays designed to detect the specific genes of Mannheimia haemolytica, Pasteurella multocida, Mycoplasma bovis, bovine viral diarrhea virus, bovine herpesvirus -1 , bovine parainfluenza virus-3, and bovine coronavirus yielded negative results. Phylogenetic analyses suggest that the isolates of $H$. somni circulating in Brazil are similar to those identified elsewhere, while there seem to be diversity between the isolates of BRSV within cattle herds from different geographical locations of Brazil.
\end{abstract}

Key words: Bronchopneumonia. Respiratory disease. Molecular diagnostics. Phylogenetic relationships.

\section{Resumo}

A Doença Respiratória Bovina (DRB) é uma infecção multifatorial e multietiológica que ocasiona aumento nas taxas de morbidade e mortalidade em confinamentos bovinos. As informações disponíveis

\footnotetext{
${ }^{1}$ Profs. Drs., Departamento de Medicina Veterinária Preventiva, UEL, Londrina, PR, Brasil. E-mail: selwyn.headley@uel.br; aalfieri@uel.br; alfieri@uel.br

2 Discente, Programa de Pós-Graduação em Ciência Animal, UEL, Londrina, PR, Brasil. E-mail: lubalbo.vet@gmail.com

3 Prof. Dr., Universidade Federal de Uberlândia, UFU, Uberlândia, MG, Brasil. E-mail: jpsaut@ufu.br

${ }^{4}$ Descente, Curso de Medicina Veterinária, Universidade Federal de Uberlândia, UFU, Uberlândia, MG, Brasil. E-mail: anderson. lopes@acproteina.com.br

* Author for coerrepondence
} 
com relação à ocorrência de DRB no Brasil e sua associação com agentes infecciosos são ainda ocasionais. Esse estudo avaliou a participação de agentes infecciosos relacionados à DRB em um confinamento de bovinos na região sudeste do Brasil. Swabs nasofaríngeos de $11 \%(n=10)$ dos bovinos ( $n=90)$ com sinais clínicos de DRB em um lote de 450 animais foram analisados por técnicas moleculares para amplificação de genes específicos dos principais patógenos relacionados à DRB. Adicionalmente, fragmentos de pulmão de um dos animais, que morreu por DRB foi coletado para diagnóstico histopatológico e molecular. O ácido nucleico de Histophilus somni e do vírus respiratório sincicial bovino (BRSV) foi identificado em 20\% (2/10) dos swabs nasofaríngeos. Em outro animal foi possível amplificar apenas o RNA do BRSV. O ácido nucleico de ambos os patógenos foi amplificado a partir de fragmentos pulmonares, que na histopatologia apresentou evidências de broncopneumonia e pneumonia intersticial. A partir do swab nasofaríngeo desse animal também foi possível amplificar o ácido nucleico de ambos os patógenos. Adicionalmente, todas as reações de PCR e RT-PCR realizadas para amplificar genes específicos de Mannheimia haemolytica, Pasteurella multocida, Mycoplasma bovis, vírus da diarreia viral bovina, herpesvírus bovino 1, vírus parainfluenza bovino 3 e coronavírus bovino foram negativas. Esses resultados confirmam a participação do $H$. somni e do BRSV no desenvolvimento de DRB em bovinos confinados no Brasil e abrem a perspectiva da realização de estudos mais amplos com o objetivo de identificar os principais agentes etiológicos da DRB no Brasil.

Palavras-chave: Broncopneumonia. Doença respiratória. Diagnóstico molecular. Relações filogenéticas.

\section{Introduction}

The bovine respiratory disease (BRD) complex is a multifactorial and multi-etiological entity that is associated with several infectious agents (GRIFFIN et al., 2010; TAYLOR et al., 2010), coupled with management (TAYLOR et al., 2010), as well as environmental factors (SNOWDER et al., 2006; TAYLOR et al., 2010). BRD is the most important cause of livestock mortality in USA feedlots and is responsible for $16 \%$ of the number of non-predator losses to beef cattle (USDA, 2011). Bacterial pathogens frequently associated with BRD include Mannheimia haemolytica, Pasteurella multocida, Histophilus somni, and Mycoplasma bovis (GAGEA et al., 2006; GRIFFIN et al., 2010; FRANCOZ et al., 2015). Viral agents commonly identified in cattle with BRD are bovine viral diarrhea virus (BVDV), bovine respiratory syncytial virus (BRSV), bovine herpesvirus -1 (BoHV-1), bovine parainfluenza virus-3 (BPIV3 ), and bovine coronavirus, BoCV (GAGEA et al., 2006; O'NEILL et al., 2014; FRANCOZ et al., 2015). In most cases, viral agents are considered as primary or predisposing factors to bacterial agents, due to the immunodepressive effects on the affected animal.
Most studies that have investigated the occurrence of disease pathogens associated with BRD were done predominantly in North America (GAGEA et al., 2006; GRIFFIN et al., 2010; TAYLOR et al., 2010; FRANCOZ et al., 2015) and Australia (CUSACK et al., 2003). Data relative to the occurrence of BRD in Brazil is sparse. We have theorized that $H$. somni might be a threat to beef cattle feedlots due to the continual diagnosis of this pathogen in respiratory (HEADLEY et al., 2014), reproductive (HEADLEY et al., 2015b), systemic (HEADLEY et al., 2013), and neurological (HEADLEY et al., 2015a) disease syndromes in cattle from different geographical regions of Brazil. Further, BRSV was associated with BRD in several herds from the state of Rio Grande do Sul, Southern Brazil (DRIEMEIER et al., 1997; BRASIL et al., 2013), while a retrospective study identified antigens of BRSV in cattle with bronchointerstitial pneumonia from Southern and Southeastern Brazil (FLORES et al., 2000). In addition, a recent study has demonstrated the participation of multiple infectious agents with the development of BRD in a dairy cattle herd from Paraná state, Southern Brazil (OLIVEIRA, 2014). This study investigated the infectious causes of respiratory disease affecting a beef cattle feedlot from Southeastern Brazil. 


\section{Materials and Methods}

Study location, animals, and clinical manifestations

This beef cattle feedlot is located on the outskirts of the city of Santa Cruz do Rio Pardo, within the state of São Paulo, Southeastern Brazil. All steers $(n=5,000)$ at the feedlot were predominantly a crossbreed of Nelore with an industrial breed of cattle, were approximately of 20 months-of-age, and maintained in feeding pens that housed 150 animals. Cattle were acquired from several small farmers from the state of São Paulo; these were initially introduced into pastures for approximately 6-10 months, and then transferred into the feedlot for fattening, where they remained for an average of 110 days. Further, this feedlot operates from June to December yearly, with respiratory disease being predominant between the months of June - October, corresponding to the dry season at this geographical location.

The consulting veterinarian indicated that cattle at this feedlot were constantly affected by respiratory disease during the last five years, but the situation became aggravated during 2014 where $20 \%(90 / 450)$ of animals from three pens within the feedlot became severely ill and $8.9 \%(8 / 90)$ of these died due to respiratory discomfort. He also related that most affected cattle were prostrated with severe nasal secretions and were medicated with a single administration of a combination of oxytetracycline and enrofloxacin; most $(80 \%)$ of the medicated animals recuperated. Further, the animals at this feedlot were routinely immunized against clostridial diseases and foot-and-mouth disease.

\section{Collection of biological samples}

Nasopharyngeal swabs were randomly collected from $11 \%(10 / 90)$ of the animals with clinical manifestations of pulmonary distress and submitted for the molecular identification of pathogens associated with BRD. All nasopharyngeal samples were immersed in sterile tubes containing phosphate buffered saline ( $\mathrm{pH} 7.2$ ), shipped on ice baths, and maintained at $-80{ }^{\circ} \mathrm{C}$ until processed for molecular diagnostics.

In addition, pulmonary fragments from one of the animals that died were collected for molecular diagnosis; duplicate sections were fixed by emersion in $10 \%$ formalin solution for histopathological evaluation. A nasopharyngeal swab was also obtained from this animal before spontaneous death.

Molecular characterization of infectious agents associated with BRD

Nucleic acids extracted from the nasopharyngeal swabs and the pulmonary tissue as described (BOOM et al., 1990), were used in PCR/RTPCR assays designed to amplify specific genes of principal infectious agents associated with BRD. Bacterial pathogens targeted included: H. somni (ANGEN et al., 1998), M. haemolytica (ANGEN et al., 2009), M. bovis (SUBRAMANIAM et al., 1998), and P. multocida (TOWNSEND et al., 1998). The identification of viral pathogens of BRD was done by evaluating the presence of specific genes of BoHV-1 (CLAUS et al., 2005), BVDV (VILČEK et al., 1994), BPIV-3 (ZHU et al., 2011), BoCV (TAKIUCHI et al., 2006), and BRSV (ALMEIDA et al., 2005).

Positive controls included DNA/RNA from cell culture adapted Los Angeles strain of BoHV1 (CLAUS et al., 2005) and the NADL strain of BVDV. DNA/RNA of $H$. somni (HEADLEY et al., 2013), BPIV-3, BoCV, and BRSV (OLIVEIRA, 2014) were obtained from previous studies and from housekeeping samples (Mycoplasma spp.). Nuclease-free water was used as negative controls in all PCR assays. PCR products were separated by electrophoresis in $2 \%$ agarose gels, stained with ethidium bromide, and examined under ultraviolet light. The amplified PCR products were then purified (PureLink Quick Gel Extraction \& PCR Purification Combo Kit, Life Technologies, São Paulo, Brazil) and submitted for direct sequencing 
using the forward and reverse primers. Sequencing was performed by using a BigDye ${ }^{\circledR}$ Terminator v3.1 Cycle Sequencing Kit (BigDye Terminator v3.1 Cycle Sequencing Kit, Applied Biosystems, Carlsbad, CA) in a 3500 Genetic Analyzer (3500 Genetic Analyzer for Resequencing \& Fragment Analysis, Applied Biosystems, Carlsbad, CA) sequencer.

Sequence quality analyses and consensus sequences were obtained using the Phred/CAP3 software (http://asparagin.cenargen.embrapa.br/ $\mathrm{phph} /$ ). The partial nucleotide sequences were initially compared by the BLAST program (http://
www.ncbi.nlm.nih.gov/BLAST) with similar sequences deposited in GenBank. Sequence alignment and phylogenetic tree were created using MEGA 6 (TAMURA et al., 2011), after which Model selection indicated the Jukes-Cantor model as being the most appropriate for determination of the phylogenetic relationship with the Maximum Likelihood method (Figures 1 and 2). The initial tree for the heuristic search were obtained by applying the Neighbor-Joining method to a matrix of pairwise distances estimated using the Maximum Composite Likelihood approach. Reference strains of BRSV were included within the phylogenetic analysis.

Figure 1. The phylogenetic relationship of selected strains of Histophilus somni based on the 16S rRNA gene of the Pasteurellaceae family. The evolutionary history was inferred by using the Maximum Likelihood method based on the Jukes-Cantor model. The tree is drawn to scale, with branch lengths measured in the number of substitutions per site; the analysis involved 40 nucleotide sequences. The isolates from this study are highlighted (box); the GenBank accession numbers and country of origin of the sequences used are given. E. coli was used as the out-group.

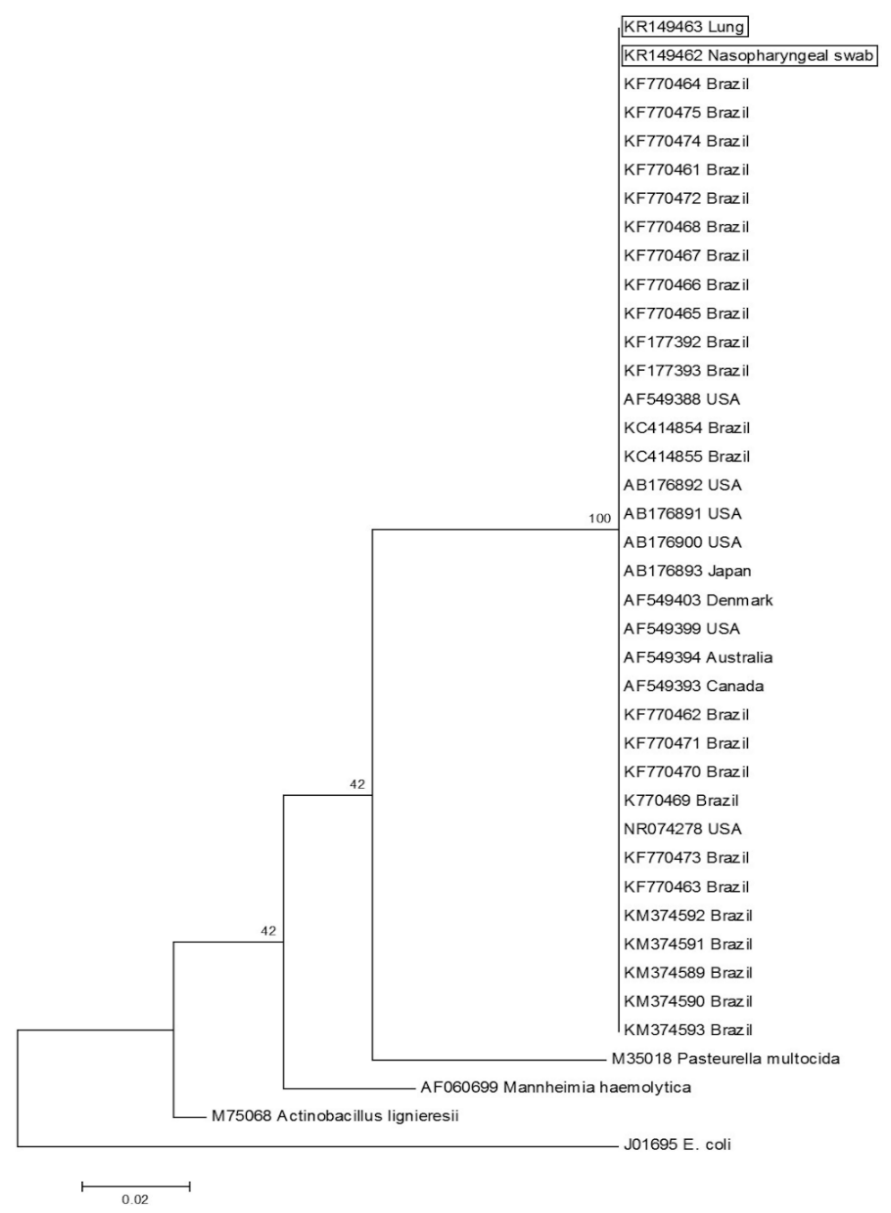


Figure 2. The phylogenetic relationship of selected strains of bovine respiratory syncytial virus based on the glycoprotein gene. The evolutionary history was inferred by using the Maximum Likelihood method based on the Jukes-Cantor model. The tree is drawn to scale, with branch lengths measured in the number of substitutions per site; the analysis involved 43 nucleotide sequences. The isolates from this study are highlighted (box); the GenBank accession numbers and BRSV groups and subgroups are shown; the isolate names are given in brackets. Ovine respiratory syncytial virus was used as the out-group.

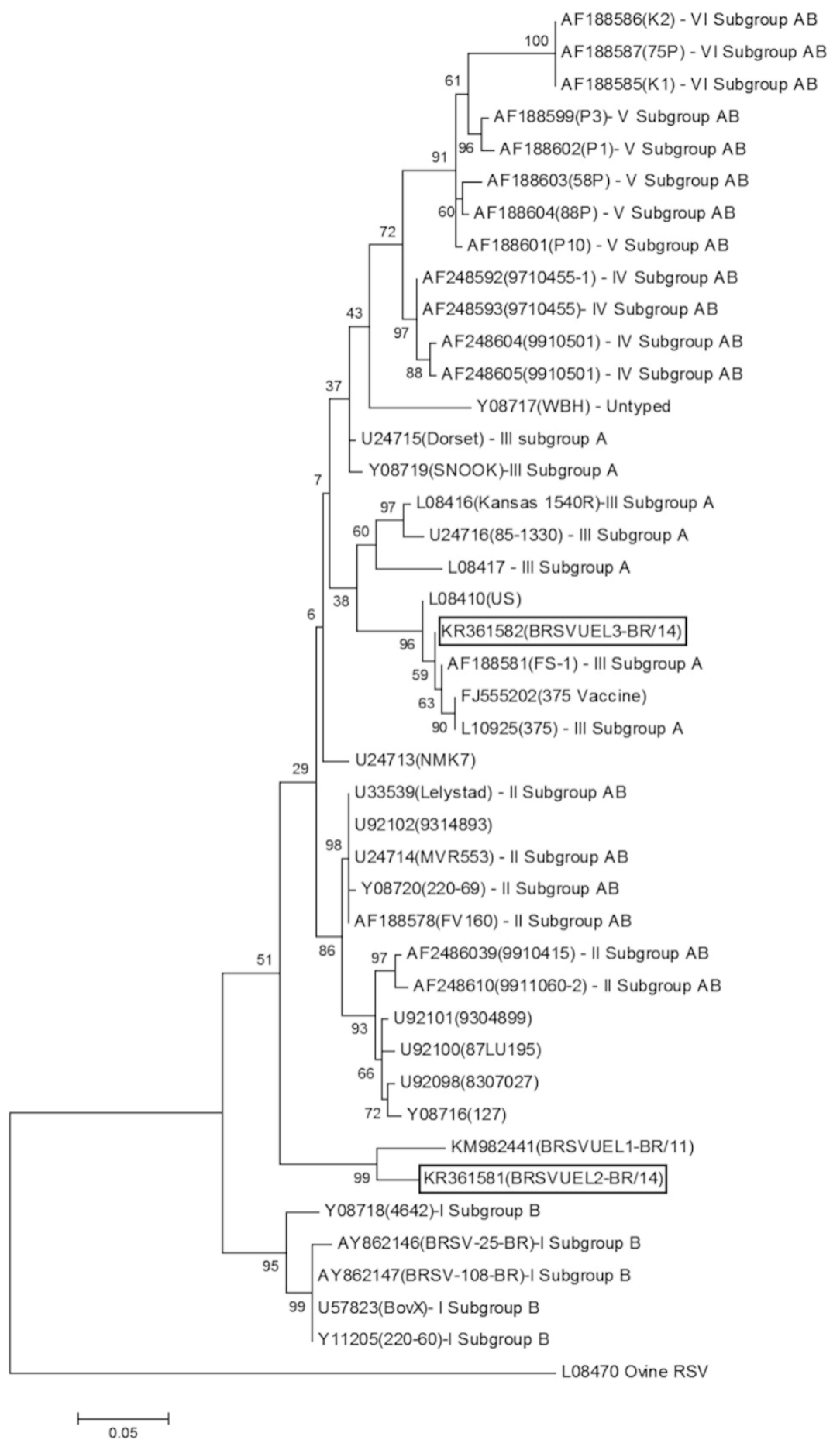




\section{Results}

\section{Pathological findings}

Grossly, the pulmonary fragments received demonstrated distension of the interlobular septa with areas of pulmonary consolidation. Histopathology, revealed thickening of alveolar walls due to the proliferation of type II pneumocytes associated with an influx of foamy macrophages, lymphocytes and plasma cells; several syncytial cells were observed. Additionally, there was marked hyperplasia of bronchiolar and bronchial epithelium with intraluminal accumulations of a mixed exudate, consisting of neutrophils and mononuclear cells. In other pulmonary fragments, there were accumulations of neutrophilic exudate within the bronchiolar and bronchial lumens and pleural fibrosis.
Molecular identification of agents associated with $B R D$

Only the BRSV and $H$. somni PCRs amplified the desired amplicons from nasopharyngeal swabs and the pulmonary tissue of the animal that died. BRSV RNA was identified from 30\% (3/10) of the nasopharyngeal swabs derived from the animals with clinical manifestations of BRD (Table 1). Additionally, 20\% (2/10) of these swabs also contained H. somni DNA, resulting with the nucleic acids of BRSV and $H$. somni being concomitantly identified in these animals. In addition, the nucleic acids of both agents (BRSV and H. somni) were amplified from the pulmonary fragments of the animal that died. Consequently, these agents were identified from the nasopharyngeal swab as well as the pulmonary fragments of this animal. All other PCR and/or RT-PCR assays yielded negative results.

Table 1. Distribution of the DNA/RNA of infectious agents in the nasopharyngeal swabs of cattle with clinical manifestations of bovine respiratory disease.

\begin{tabular}{|c|c|c|c|c|c|c|c|c|c|c|}
\hline \multirow{2}{*}{$\begin{array}{c}\text { Infectious agents associated } \\
\text { with BRD }\end{array}$} & \multicolumn{10}{|c|}{ Animal \# } \\
\hline & 1 & 2 & 3 & 4 & 5 & 6 & 7 & 8* & 9 & 10 \\
\hline \multicolumn{11}{|l|}{ Bovine herpesvirus-1 } \\
\hline \multicolumn{11}{|l|}{ Bovine coronavirus } \\
\hline \multicolumn{11}{|l|}{ Bovine viral diarrhea virus } \\
\hline \multicolumn{11}{|l|}{ Bovine parainfluenza-3 } \\
\hline Bovine respiratory syncytial virus & & & & + & + & & & +1 & & \\
\hline \multicolumn{11}{|l|}{ Mannheimia haemolytica } \\
\hline \multicolumn{11}{|l|}{ Pasteurella multocida } \\
\hline Histophilus somni & & & & + & & & & +1 & & \\
\hline Mycoplasma bovis & & & & & & & & & & \\
\hline
\end{tabular}

* This animal was necropsied and the pulmonary fragments contained H. somni DNA and BRSV RNA.

${ }^{1}$ Samples used for sequencing.

Direct sequencing of $H$. somni PCR products was done only from the pulmonary fragment (\# 4) and nasopharyngeal swab of the animal (\#8) that died. Initial BLAST analyses revealed that these sequences (GenBank Accession \# KR149463, lung; KR149462, nasopharyngeal swab) share $100 \%$ identity with similar sequences deposited in GenBank. Further, the generated phylogenetic relationship revealed that the isolates identified from this study clustered with similar isolates of H. somni deposited in GenBank (Figure 1). In addition, all isolates of $H$. somni formed a definite group from other members of the Pasteurellaceae family. 
Direct sequencing of the BRSV products was done from animal \# 4 and 8. Initial Blast analyses revealed that these sequences (GenBank Accessions \# KR361581, KR361582, both derived from nasopharyngeal swabs) shared $99-100 \%$ sequence identity with similar isolates of the glycoprotein gene of BRSV deposited in GenBank. The phylogenetic relationship (Figure 2) revealed that one of the isolates from this study (KR361582, termed isolate BRSVUEL-BR3) clustered with other strains of the BRSV genetic subgroup A (group III). The other (KR361581, referred to as isolate BRSVUEL-BR2) formed a definite cluster with another uncharacterized strain of BRSV recently identified by our group from the state of Paraná, Southern Brazil (OLIVEIRA, 2014); other isolates from Brazil clustered within the subgroup B (group I) strain of BRSV.

\section{Discussion}

This study has demonstrated the presence of BRSV RNA and $H$. somni DNA in the nasopharyngeal swabs of some of the affected cattle and the pulmonary fragments of one feedlot animal with acute pulmonary distress. Further, this is the first study done in Brazil that has demonstrated the simultaneous participation of $H$. somni and BRSV in the development of BRD in feedlot cattle. In addition, all other RT-PCR and/or PCR assays designed to detect specific genes of BVDV, BoHV1, BPIV-3, BoCV, M. haemolytica, M. bovis, and $P$. multocida were negative. Consequently, these results indicate that BRSV and $H$. somni were involved in the development of the acute pulmonary distress in the animals evaluated at this feedlot, probably due to synergism identified between these two pathogens (AGNES et al., 2013). Moreover, this is one of the few studies done in Brazil that has effectively investigated the infectious agents associated with BRD in beef cattle feedlots; we have previously demonstrated H. somni and BoHV1 associated with respiratory disease in a beef cattle feedlot (HEADLEY et al., 2014), and multiple infectious agents were associated with BRD in dairy cattle (OLIVEIRA, 2014). Although other groups only investigated and confirmed the participation of BRSV in cattle reared in feedlots (BRASIL et al., 2013) and extensively (DRIEMEIER et al., 1997; FLORES et al., 2000) from diverse regions of Brazil, it is rather likely that other infectious disease pathogens associated with BRD might have been identified if these were investigated. Nevertheless, these results are encouraging since the infectious agents thus far identified in feedlot cattle from Brazil with BRD are similar to agents described in North America (GAGEA et al., 2006; GRIFFIN et al., 2010; FRANCOZ et al., 2015) and Australia (CUSACK et al., 2003), where the economic setbacks of respiratory disease on feedlot cattle is been intensively investigated.

The simultaneous natural co-existence of $H$. somni and BRSV at this feedlot exemplifies the synergism due to the simultaneous colonization of the alveoli of cattle experimentally and concomitantly infected with these pathogens (AGNES et al., 2013). Further, the pulmonary histopathological findings of the animal that died of complications related to coinfections by $H$. somni and BRSV during this study were similar to those described in BRD experimentally induced in cattle, with these pathogens (GERSHWIN et al., 2005; AGNES et al., 2013). In dual infections by H. somni and BRSV, there is an increase in the accumulation of $H$. somni at the pulmonary alveolar resulting in increased retraction of pneumocytes and degradation of collagen, which enables lung damage, producing bronchopneumonia and dissemination of H. somni (AGNES et al., 2013). Consequently, this dual mechanism of pulmonary injury might be responsible for the severe pulmonary damage observed in the animal that was concomitantly infected by H. somni and BRSV during this investigation.

Although the real economic impact of BRD on feedlot cattle from Brazil is unknown, a recent 
study done by our group has estimated morbidity at $58.4 \%$ and mortality at around $0.07 \%$ (Baptista, A.L. et al. manuscript in preparation), thereby highlighting the importance of understanding the participation of BRD-related infectious agents on feedlot cattle from Brazil. Further, single and mixed infections of $H$. somni and $H$. somni with BRSV and other infectious agents have been identified in dairy calves from Southern Brazil with BRD, where predominant agents of BRD were BRSV (38.1\%), BVDV (28.6\%), BCoV (33.3\%), P. multocida (42.85\%), M. bovis (33.3\%), and H. somni (19\%) (OLIVEIRA, 2014). In addition, since $H$. somni has been increasingly diagnosed in BRD in beef cattle feedlots as well as in the development of fatal systemic (HEADLEY et al., 2013), neurological (HEADLEY et al., 2015a), and reproductive (HEADLEY et al., 2015b) disease in beef and dairy cattle herds from this country, strategic prophylactic and control measures are necessary to prevent the economic effects of widespread dissemination of this pathogen within the local cattle industry. Collectively, these findings confirmed the theory that $H$. somni is indeed a potential threat to the cattle industry of Brazil (HEADLEY et al., 2014), where immunization against this important pathogen of ruminants is almost nonexistent. Further, when the results from this and other studies (DRIEMEIER et al., 1997; FLORES et al., 2000; BRASIL et al., 2013; OLIVEIRA, 2014) are considered, BRSV seems to be an important viral pathogen associated with BRD in cattle from Brazil.

Although the outbreak of BRD occurred predominantly during the dry dusty season with low precipitation levels, changes in weather patterns seems not to have any direct effects on the increased yearly occurrence of fibrinous bronchopneumonia in feedlot cattle from North America (RIBBLE et al., 1995). Nevertheless, changes in weather conditions have been identified as one of the probable factors that might have contributed to an increase in BRD (LONERAGAN et al., 2001) and we have observed a significant increase of BRD in feedlot cattle during the dry relative to wet season (Baptista et al. manuscript in preparation). However, the direct effects of climatic conditions per se as predisposing factors to the development of BRD has been questioned due to the absence of solid scientific data to support this theory (TAYLOR et al., 2010).

Another possible stressor identified during this study was feedyard dust, which was associated with an increase in BRD (MACVEAN et al., 1986). However, an experimental study did not demonstrate differences in pulmonary disease in cattle that were exposed or relative to those not exposed to dust particles (PURDY et al., 2003).Consequently, the climatic conditions during the dry dusty period might per se not have any direct effect on the development of BRD observed during this investigation, but when coupled with concomitant infectious pathogens, management and genetic factors can have an impact on the pathogenesis of BRD (TAYLOR et al., 2010). However, it must be highlighted that the onset of respiratory disease began long after the affected animals were conditioned within the feedlot, and not within the first few days/weeks on feed as is frequently described in BRD from North America (RIBBLE et al., 1995; GAGEA et al., 2006). This is because at this feedyard, all acquired animals are initially maintained on pastures for months and then transferred into the feedlot. Nevertheless, we are conducting nationwide surveys to investigate and understand the complexities of the factors associated with BRD in beef cattle feedlots in Brazil in an attempt to see if the non-infectious factors of this disease complex is similar to those described in North America and Australia.

The phylogenetic analyses of the $H$. somni isolates suggests that the strains identified during this investigation are similar to other isolates from different geographical locations. However, one of the BRSV isolates identified (KR361582, termed isolate BRSVUEL-BR3) during this study clustered with an established group of BRSV strains of organisms (SPILKI et al., 2006), while the other 
isolate from the state of São Paulo clustered with another untyped (unclassified) strain of BRSV identified in cattle from the state of Paraná; these formed a distinct cluster. Nevertheless, both strains identified during this study clustered in groups that did not contain previously identified isolates of BRSV from Brazil that were clustered in subgroup B (ALMEIDA et al., 2006; SPILKI et al., 2006). Interestingly, all isolates of BRSV thus far identified were from different geographical regions of Brazil. Consequently, the results of phylogenetic analysis suggest that there was more than one strain of BRSV at this feedlot and that there is diversity within the isolates of BRSV circulating in cattle from Brazil. Further, these results are in agreement with the idea that new isolates of BRSV are likely to emerge (ALMEIDA et al., 2006) as more strains are identified and characterized across Brazil.

\section{Conclusions}

The nucleic acids of BRSV and H. somni were identified in cattle with clinical manifestations associated with and in one animal that died of BRD from Southeastern Brazil. These results suggest that H. somni is indeed a threat to the local cattle industry, particularly when infections are associated with BRSV and that there is diversity within the isolates of BRSV circulating in different geographical regions of Brazil. Although the investigation of the factors associated with BRD in Brazil is incipient, these results will form the base to understand the factors associated with BRD in this country.

\section{Acknowledgements}

S. A. Headley, A. F. Alfieri, J. P. E. Saut, and A. A. Alfieri are recipients of the National Council for Scientific and Technological Development (CNPq; Brazil) fellowships and grants. This study was partially funded by a CNPq grant (process \# CNPq $n^{\circ} 448797 / 2014-3$ ).

\section{References}

AGNES, J. T.; ZEKARIAS, B.; SHAO, M.; ANDERSON, M. L.; GERSHWIN, L. J.; CORBEIL, L. B. Bovine respiratory syncytial virus and Histophilus somni interaction at the alveolar barrier. Infection and Immunity, Washington, DC, v. 81, n. 7, p. 2592-2597, 2013.

ALMEIDA, R. S.; DOMINGUES, H. G.; SPILKI, F. R.; LARSEN, L. E.; HAGGLUND, S.; BELAK, S.; ARNS, C. W. Circulation of bovine respiratory syncytial virus in Brazil. Veterinary Record, London, v. 158, n. 18, p. 632-634, 2006.

ALMEIDA, R. S.; SPILKI, F. R.; ROEHE, P. M.; ARNS, C. W. Detection of Brazilian bovine respiratory syncytial virus strain by a reverse transcriptase-nestedpolymerase chain reaction in experimentally infected calves. Veterinary Microbiology, Amsterdam, v. 105, n. 2, p. 131-135, 2005.

ANGEN, O.; AHRENS, P.; TEGTMEIER, C. Development of a PCR test for identification of Haemophilus somnus in pure and mixed cultures. Veterinary Microbiology, Amsterdam, v. 63, n. 1, p. 3948, 1998.

ANGEN, O.; THOMSEN, J.; LARSEN, L. E.; LARSEN, J.; KOKOTOVIC, B.; HEEGAARD, P. M.; ENEMARK, J. M. Respiratory disease in calves: microbiological investigations on trans-tracheally aspirated bronchoalveolar fluid and acute phase protein response. Veterinary Microbiology, Amsterdam, v. 137, n. 1-2, p. 165-171, 2009.

BOOM, R.; SOL, C. J.; SALIMANS, M. M.; JANSEN, C. L.; WERTHEIM-VAN DILLEN, P. M.; VAN DER NOORDAA, J. Rapid and simple method for purification of nucleic acids. Journal of Clinical Microbiology, Washington, v. 28, n. 3, p. 495-503, 1990.

BRASIL, N. D. A.; HINNAH, F. L.; FISS, L.; SALLIS, E. S. V.; GRECCO, F. B.; LADEIRA, S. R. L.; MARCOLONGO-PEREIRA, C.; SCHILD, A. L. Respiratory diseases in calves in southern Rio Grande do Sul: study of 33 outbreaks. Pesquisa Veterinária Brasileira, Seropédica, v. 33, n. 6, p. 745-751, 2013.

CLAUS, M. P.; ALFIERI, A. F.; FOLGUERASFLATSCHART, A. V.; WOSIACKI, S. R.; MEDICI, K. C.; ALFIERI, A. A. Rapid detection and differentiation of bovine herpesvirus 1 and 5 glycoprotein $\mathrm{C}$ gene in clinical specimens by multiplex-PCR. Journal of Virological Methods, Amsterdam, v. 128, n. 1-2, p. 183188, 2005. 
CUSACK, P. M.; MCMENIMAN, N.; LEAN, I. J. The medicine and epidemiology of bovine respiratory disease in feedlots. Australian Veterinary Journal, Sydney, v. 81, n. 8 , p. $480-487,2003$.

DRIEMEIER, D.; GOMES, M. J. P.; MOOJEN, V.; ARNS, C. W.; VOGG, G.; KESSLER, L.; COSTA, U. M. D. Clinic-pathological aspects in the natural infection of Bovine Respiratory Syncytial Virus (BRVS) in extensive management of cattle in Rio Grande do Sul, Brazil. Pesquisa Veterinária Brasileira, Seropédica, v. 17, p. 7781, 1997.

FLORES, E. F.; WEIBLEN, R.; MEDEIROS, M.; BOTTON, S. A.; IRIGOYEN, L. F.; DRIEMEIER, D.; SCHUCH, L. F.; MORAES, M. A retrospective search for bovine respiratory syncytial virus (BRSV) antigens in histological specimens by immunofluorescence and immunohistochemistry. Pesquisa Veterinária Brasileira, Seropédica, v. 20, p. 139-143, 2000.

FRANCOZ, D.; BUCZINSKI, S.; BELANGER, A. M.; FORTE, G.; LABRECQUE, O.; TREMBLAY, D.; WELLEMANS, V.; DUBUC, J. Respiratory pathogens in Quebec dairy calves and their relationship with clinical status, lung consolidation, and average daily gain. Journal of Veterinary Internal Medicine, Philadelphia, v. 29, n. 1, p. 381-387, 2015.

GAGEA, M. I.; BATEMAN, K. G.; VAN DREUMEL, T.; MCEWEN, B. J.; CARMAN, S.; ARCHAMBAULT, M.; SHANAHAN, R. A.; CASWELL, J. L. Diseases and pathogens associated with mortality in Ontario beef feedlots. Journal of Veterinary Diagnostic Investigation, Columbia, v. 18, n. 1, p. 18-28, 2006.

GERSHWIN, L. J.; BERGHAUS, L. J.; ARNOLD, K.; ANDERSON, M. L.; CORBEIL, L. B. Immune mechanisms of pathogenetic synergy in concurrent bovine pulmonary infection with Haemophilus somnus and bovine respiratory syncytial virus. Veterinary Immunology and Immunopathology, Amsterdam, v. 107, n. 1-2, p. 119-130, 2005.

GRIFFIN, D.; CHENGAPPA, M. M.; KUSZAK, J.; MCVEY, D. S. Bacterial pathogens of the bovine respiratory disease complex. Veterinary Clinics of North America: Food Animal Practice, Philadelphia, v. 26, n. 2, p. 381-394, 2010.

HEADLEY, S. A.; ALFIERI, A. F.; OLIVEIRA, V. H.; BEUTTEMMULLER, E. A.; ALFIERI, A. A. Histophilus somni is a potential threat to beef cattle feedlots in Brazil. Veterinary Record, London, v. 175, n. 10, p. 249, 2014.

HEADLEY, S. A.; BRACARENSE, A. P. F. R. L.; OLIVEIRA, V. H. S.; QUEIROZ, G. R.; OKANO, W.; ALFIERI, A. F.; FLAIBAN, K. K. M. C.; LISBÔA,
J. A. N.; ALFIERI, A. A. Histophilus somni-induced thrombotic meningoencephalitis in cattle from northern Paraná, Brazil. Pesquisa Veterinária Brasileira, Seropédica, v. 35, n. 4, p. 329-336, 2015 a.

HEADLEY, S. A.; OLIVEIRA, V. H.; FIGUEIRA, G. F.; BRONKHORST, D. E.; ALFIERI, A. F.; OKANO, W.; ALFIERI, A. A. Histophilus somni-induced infections in cattle from southern Brazil. Tropical Animal Health and Production, Edinburgh, v. 45, n. 7, p. 1579-1588, 2013.

HEADLEY, S. A.; VOLTARELLI, D.; OLIVEIRA, V. H. S.; BRONKHORST, D. E.; ALFIERI, A. F.; NEGRI, L. C.; OKANO, W.; ALFIERI, A. A. Association of Histophilus somni with spontaneous abortions in dairy cattle herds from Brazil. Tropical Animal Health and Production, Edinburgh, v. 47, n. 2, p. 403-413, 2015 b.

LONERAGAN, G. H.; DARGATZ, D. A.; MORLEY, P. S.; SMITH, M. A. Trends in mortality ratios among cattle in US feedlots. Journal of the American Veterinary Medical Association, Schaumburg, v. 219, n. 8, p. 11221127, 2001.

MACVEAN, D. W.; FRANZEN, D. K.; KEEFE, T. J.; BENNETT, B. W. Airborne particle concentration and meteorologic conditions associated with pneumonia incidence in feedlot cattle. American Journal of Veterinary Research, Schaumburg, v. 47, n. 12, p. 26762682, 1986.

O'NEILL, R.; MOONEY, J.; CONNAGHAN, E.; FURPHY, C.; GRAHAM, D. A. Patterns of detection of respiratory viruses in nasal swabs from calves in Ireland: a retrospective study. Veterinary Record, London, v. 175, n. 14, p. 351, 2014.

OLIVEIRA, V. H. S. Diagnóstico molecular de infecções virais e bacterianas associadas a um surto de doença respiratória em bezerras leiteiras. 2014. (Dissertação de Mestrado) - Departamento de Medicina Veterinária Preventiva, Universidade Estadual de Londrina, Paraná, Brasil.

PURDY, C. W.; STRAUS, D. C.; CHIRASE, N.; AYERS, J. R.; HOOVER, M. D. Effects of aerosolized dust in goats on lung clearance of Pasteurella and Mannheimia species. Current Microbiology, New York, v. 46, n. 3, p. 174-179, 2003.

RIBBLE, C. S.; MEEK, A. H.; JANZEN, E. D.; GUICHON, P. T.; JIM, G. K. Effect of time of year, weather, and the pattern of auction market sales on fatal fibrinous pneumonia (shipping fever) in calves in a large feedlot in Alberta (1985-1988). Canadian Journal of Veterinary Research, Ottawa, v. 59, n. 3, p. 167-172, 1995. 
SNOWDER, G. D.; VAN VLECK, L. D.; CUNDIFF, L. V.; BENNETT, G. L. Bovine respiratory disease in feedlot cattle: environmental, genetic, and economic factors. Journal of Animal Science, Champaign, v. 84, n. 8, p. 1999-2008, 2006.

SPILKI, F. R.; ALMEIDA, R. S.; DOMINGUES, H. G.; D'ARCE, R. C.; FERREIRA, H. L.; CAMPALANS, J.; COSTA, S. C.; ARNS, C. W. Phylogenetic relationships of Brazilian bovine respiratory syncytial virus isolates and molecular homology modeling of attachment glycoprotein. Virus Research, Amsterdam, v. 116, n. 1-2, p. 30-37, 2006.

SUBRAMANIAM, S.; BERGONIER, D.; POUMARAT, F.; CAPAUL, S.; SCHLATTER, Y.; NICOLET, J.; FREY, J. Species identification of Mycoplasma bovis and Mycoplasma agalactiae based on the uvrC genes by PCR. Molecular and Cellular Probes, London, v. 12, n. 3, p. 161-169, 1998.

TAKIUCHI, E.; STIPP, D. T.; ALFIERI, A. F.; ALFIERI, A. A. Improved detection of bovine coronavirus $\mathrm{N}$ gene in faeces of calves infected naturally by a semi-nested PCR assay and an internal control. Journal of Virological Methods, Amsterdam, v. 131, n. 2, p. 148-154, 2006.

TAMURA, K.; PETERSON, D.; PETERSON, N.; STECHER, G.; NEI, M.; KUMAR, S. MEGA5: molecular evolutionary genetics analysis using maximum likelihood, evolutionary distance, and maximum parsimony methods. Molecular Biology and Evolution, New York, v. 28, n. 10, p. 2731-2739, 2011.
TAYLOR, J. D.; FULTON, R. W.; LEHENBAUER, T. W.; STEP, D. L.; CONFER, A. W. The epidemiology of bovine respiratory disease: What is the evidence for predisposing factors? Canadian Veterinary Journal, Ottawa, v. 51, n. 10, p. 1095-1102, 2010.

TOWNSEND, K. M.; FROST, A. J.; LEE, C. W.; PAPADIMITRIOU, J. M.; DAWKINS, H. J. S. Development of PCR assays for species- and typespecific identification of Pasteurella multocida isolates. Journal of Clinical Microbiology, Washington, v. 36, n. 4, p. 1096-1100, 1998.

UNITED STATES DEPARTMENT OF AGRICULTURE - USDA. Cattle and calves nonpredator death loss in the United States 2010. USDA-APHIS-VS-CEAH. Fort Collins, CO, 2011.

VILČEK, S̆.; HERRING，A. J.; HERRING，J. A.; NETTLETON, P. F.; LOWINGS, J. P.; PATON, D. J. Pestiviruses isolated from pigs, cattle and sheep can be allocated into at least three genogroups using polymerase chain reaction and restriction endonuclease analysis. Archives of Virology, Wien, v. 136, n. 3, p. 309-323, 1994.

ZHU, Y.-M.; SHI, H.-F.; GAO, Y.-R.; XIN, J.-Q.; LIU, N.H.; XIANG, W.-H.; REN, X.-G.; FENG, J.-K.; ZHAO, L.-P.; XUE, F. Isolation and genetic characterization of bovine parainfluenza virus type 3 from cattle in China. Veterinary Microbiology, Amsterdam, v. 149, n. 3-4, p. 446-451, 2011. 
